\title{
Developments of the CEE banking sectors after the financial crisis
}

\author{
Magdalena RADULESCU \\ University of Pitesti, Faculty of Economic Sciences and Law, Departament of Finance and \\ Accounting, Pitesti, Str. Targu din Vale, No.1, Arges, Romania \\ youmagdar@yahoo.com (corresponding author)
}

\section{Logica BANICA}

University of Pitesti, Faculty of Economic Sciences and Law, Departament of Finance and Accounting, Pitesti, Str. Targu din Vale, No.1, Arges, Romania olga_banica@yahoo.com

\author{
Crenguta Ileana SINISI \\ University of Pitesti, Faculty of Economic Sciences and Law, Departament of Management \\ and Business Administration, Pitesti, Str. Targu din Vale, No.1, Arges, Romania \\ crengutaileana77@gmail.com
}

\begin{abstract}
The banking sectors of the Central and Eastern European countries performed better than other developed European sectors during the crisis, due to their sound capitalization and a high profitability before the crisis. However, some of those banking systems were very hit in terms of the non-performing loans ratio or cost-to-income ratio. That is why we consider that it is interesting to see how they performed in terms of the banking performance ratios during the last years in the light of the new international capital adequacy regulations and in the light of the latest national macroeconomic developments of those economies and what are the main threats for these CEE banking sectors in the present.
\end{abstract}

Keywords: capitalization ratio, profitability ratios, cost-to-income ratio, liquidity ratio, nonperforming loans ratio, Central and Eastern European banking sectors.

\section{Introduction}

According to Athanasoglou et al. (2008), a sound and profitable banking sector is better able to fight negative shocks and contribute to the stability of the financial system. Claeys and Vander Vennet (2008) found out that capital adequacy impacts on the interest bank margin and supports stability and profitability of the banking systems in the CEE accession countries.

An important challenge for the European banking sector is related to the difficulties in increasing revenues because of a low nominal growth and a low interest rate environment (Constâncio, 2016).

Demirgüç-Kunt and Huizinga (1999), Mendes and Abreu (2003), Goddard et al. (2004), Pasiouras and Kosmidou (2007) concluded that the most performing are the banks with high equity. Beltratti and Stulz (2012) emphasized that banks got better performance in the countries with strict capital adequacy requirements. But banks from countries with powerful supervision authorities recorded low market returns, as the shareholders were asked to raise new equity during the crisis period.

The equity level has a positive impact on ROA. Although the ownership nature has an insignificant impact on the bank profits, it may be stated that the crisis had a lower effect in terms of asset profitability on the foreign owned than on domestic owned banks (except Hungary) (Andries et al., 2016). 
Capraru and Ihnatov (2014) underlined that capital adequacy growth influenced the bank profitability (ROA and ROE and net interest margin, a stronger effect being for ROE). They noticed that banks with higher capital adequacy are more profitable for 5 CEE countries during 2004-2011 (Bulgaria, Hungary, Poland, Romania, Czech Republic.

Tomuleasa and Cocris (2014) found a significant positive impact of the capital adecquacy rate on the net interest margin during 2004-2012, but this impact is negative on ROE, because of the mutations on the banking markets in the last years.

The results of Roman and Tomuleasa (2014) research show that bank profitability of most banks in the new EU member state (expressed by ROE) was significantly influenced by capital adequacy during 2003-2011 in the CEE countries, but the study of Petria et al. (2015) has shown that the capitalization ratio hasn't a significant impact on ROE for the EU banking systems (2004-2011) and has a significant positive impact only on ROA. The capital adequacy has a positive impact on the profitability of Hungarian, Polish and Romanian banks. During the recent financial crisis, it can also be observed an inverse relationship between capital adequacy and banks profitability in Bulgaria and the Czech Republic.

Thus, there is evident a positive relationship between capital and profitability as it was demonstrated by some reasearches (Altunbas et al., 2007; Iannotta et al., 2007). On the other hand, there are some papers which proved just the opposite (Agoraki et al., 2011).

In the light of the findings of the previous studies and considering the better performance of the CEE banking systems during the last crisis, the aim of this paper is to present the developments of the performance ratios of these CEE banking systems after the crisis comparing to the years before the crisis, in the light of new regulatory framework imposed internationally or at the national level.

\section{Developments of the CEE banking sectors}

In Bulgaria, domestic credit increased (especially the foreign exchange denominated credit as a result of the Currency Board Arrangement) and the Bulgarian banks were well capitalized in the first half of the 2000s', although the capital adequacy ratio displayed a descendent trend because of the increase of the risky banking assets (Walko, 2003). Bank regulatory capital to risk-weighted assets ratio decreased during 2002-2007 and reached its lowest level just before the crisis erupted in the CEE area in 2007 (13,8\%). Starting with 2008, the banking capital adequacy increased every year reaching a level around 22 percent during 2014-2015. This is way above the Basel requirements, so ROE is three times lower (around 7\%) than it was in 2008 before the crisis (21\%).

Bulgarian banks displayed decreasing ROE rates during the crisis period, below the region average. The main reasons for the weak performance were lower interest rates on

the market and high cost of the financing during the crisis. Interest and fee margins declined between 2007 and 2011, while risk costs remained at a high level. As revenues from basic lending activities grew more slowly, banks had to develop less traditional business segments such as savings (Bakor et al., 2012). After 2013, ROE started to increase slowly and now it is staying around 7,2-7,4\%.

These developments of the capitalization are very important and positive especially because we can see a strong increase for the net interest margin, but also for ROA. The improvement of the profitability is due to a strong decrease of cost-income ratio (from 60\% in 2002 to $35 \%$ in 2015). This means that banks have cut their 
operational cost and provided an efficient cost management. The liquidity of the Bulgarian banking system has also improved in 2015 (25,7\%), but the level is only comparable with the liquidity level in $2008(26,1 \%)$ when the crisis erupted and it is less than half of the level reached at the beginning of the analyzed period 2002-2004 (between 45-67\%). Provisions to non-performing loans reached in 2015 the same level $(55,8 \%)$ as at the beginning of the analyzed period 2002-2003, while during 2004-2007 this ratio was above 100 percent. So, the quality of the banking loan portfolios started to deteriorate again significantly after 2009. During the last two analyzed years 2014-2015 this ratio also displayed an increase, because the share of non-performing loans constantly increased during 2009-2015, reaching 20\% in 2015, while before the crisis this share was around $2 \%$ (Table 1 ). The credits granted to the private sector increased the entire period during 2002-2010, including the crisis period, then decreased slowly during 2011-2013 and it reached 56\% in 2015 but this level is similar with the level in 2007, before the crisis erupted (Global Financial Development Database, 2016).

So, the Bulgarian banking system remained stable, very well capitalized and its profitability improved lately based on a high level of the domestic credit that generated higher interest income and due to an efficient costs management. The interest rate spread maintained at around 6\% with low fluctuations during the entire period 20022015. Its main challenge is represented by the increase of the non-performing loans that may endanger the profitability of the Bulgarian banking system in the future (Table 1).

Table 1. Dataset for Bulgaria

\begin{tabular}{|l|r|r|r|r|r|r|r|}
\hline Indicator & 2002 & 2003 & 2004 & 2005 & 2006 & 2007 & 2008 \\
\hline Bank cost to income ratio (\%) & 60,6 & 59,1 & 56,9 & 53,3 & 50,5 & 45,9 & 46,9 \\
\hline $\begin{array}{l}\text { Liquid assets to deposits and short } \\
\text { term funding (\%) }\end{array}$ & 67,8 & 44,5 & 48,9 & 45,5 & 48,2 & 39,1 & 26,1 \\
\hline $\begin{array}{l}\text { Provisions to nonperforming loans } \\
\text { (\%) }\end{array}$ & 59,6 & 50 & 138 & 131,4 & 109,9 & 100,4 & 77,1 \\
\hline $\begin{array}{l}\text { Bank regulatory capital to risk- } \\
\text { weighted assets (\%) }\end{array}$ & 25,2 & 22 & 16,6 & 15,3 & 14,5 & 13,8 & 14,9 \\
\hline Bank net interest margin (\%) & 4,93 & 4,82 & 5,78 & 5,30 & 5,30 & 5,34 & 5,12 \\
\hline ROA (\%) & 1,9 & 2,4 & 2,1 & 2,1 & 2,2 & 2,5 & 2,3 \\
\hline ROE (\%) & 14,4 & 22,7 & 20,6 & 22,1 & 24,4 & 25,4 & 21 \\
\hline Indicator & 2009 & 2010 & 2011 & 2012 & 2013 & 2014 & 2015 \\
\hline Bank cost to income ratio (\%) & 47,5 & 48,2 & 50,5 & 52,5 & 54,0 & 37,8 & 35,1 \\
\hline $\begin{array}{l}\text { Liquid assets to deposits and short } \\
\text { term funding (\%) }\end{array}$ & 22,7 & 24,3 & 25,2 & 24,3 & 26,7 & 18,5 & 25,7 \\
\hline $\begin{array}{l}\text { Provisions to nonperforming loans } \\
\text { (\%) }\end{array}$ & 58,2 & 61,4 & 59,5 & 63 & 65,6 & 49,4 & 55,8 \\
\hline $\begin{array}{l}\text { Bank regulatory capital to risk- } \\
\text { weighted assets (\%) }\end{array}$ & 17 & 17,4 & 17,6 & 16,6 & 17 & 21,9 & 22,2 \\
\hline Bank net interest margin (\%) & 4,42 & 4,52 & 4,10 & 3,69 & 3,38 & 1,07 & 4,02 \\
\hline ROA (\%) & 1,1 & 0,9 & 0,8 & 0,7 & 0,6 & 0,8 & 1 \\
\hline ROE (\%) & 9,3 & 6,7 & 6,1 & 5 & 5,7 & 7,2 & 7,4 \\
\hline
\end{tabular}

In Bulgaria, macroeconomic environment improved in 2014. But, the banking sector could not fully benefit from the overall positive economic developments, because of the banking crisis in June 2014. The banks' total assets and total loans contracted. Despite the negative impact from the mid-year crisis, the Bulgarian banking sector 
registered a net profit in 2014 above the results of 2013. Because the total assets and the balance sheet decreased, ROA and ROE improved. In 2014, the Bulgarian banking sector faced some important legal and regulatory developments and its liquidity ratio improved. The government improved the legislation on bankruptcy for the banking sector. The nonperforming ratio reached high levels and continues to endanger the Bulgarian banking system (Raifeissen Bank, 2015).

In 2004, the Romanian banking system was characterized by a growing rate of the banking assets superior to economic growth rate, high profits and a high retail lending activity. The Romanian banking sector was adequately capitalized, but credit risk intensified especially because of the boom of the consume credit or because of the mortgage credit denominated in foreign currency. Considering the share of the nonperforming loans to total credits, Romania were among the most affected countries (with shares between around 20\%) (Avadanei, 2011).

In Romania, bank regulatory capital to risk-weighted assets ratio decreased during 2002-2008, reaching its lowest level in 2007-2008 (13,8\%) just like in Bulgaria. It started to increase after 2009 and faced a much robust increase after 2013, reaching a level of 19,2 percent in 2015. The Romanian banking system is also well-capitalized according to the Basel requirements, but its capitalization is a bit lower than the one of the Bulgarian banking system. In the light of these developments and because the profitability of the Romanian banking system turned positive again in 2015, ROE recovered partially in 2015 (at around 8\%) but this is half of its level recorded at the beginning of the analyzed period (between 15,6\%-18\% during 2002-2004) and its trend is rather fluctuant (Table 2).

Table 2. Dataset for Romania

\begin{tabular}{|c|c|c|c|c|c|c|c|}
\hline Indicator & 2002 & 2003 & 2004 & 2005 & 2006 & 2007 & 2008 \\
\hline $\begin{array}{l}\text { Bank cost to income } \\
\text { ratio (\%) }\end{array}$ & 62,9 & 69,5 & 57,6 & 66,1 & 68,3 & 63,4 & 49,0 \\
\hline $\begin{array}{l}\text { Liquid assets to deposits } \\
\text { and short term funding } \\
(\%)\end{array}$ & 65,0 & 47,3 & 51,3 & 50,0 & 57,6 & 43,3 & 32,6 \\
\hline $\begin{array}{l}\text { Provisions to } \\
\text { nonperforming loans } \\
(\%)\end{array}$ & - & 12,6 & 16,1 & 45,6 & 82 & 61,6 & 44,2 \\
\hline $\begin{array}{l}\text { Bank regulatory capital } \\
\text { to risk-weighted assets } \\
(\%)\end{array}$ & 25 & 21,1 & 20,6 & 21,1 & 18,1 & 13,8 & 13,8 \\
\hline $\begin{array}{l}\text { Bank net interest margin } \\
(\%)\end{array}$ & 8,10 & 7,70 & 8,75 & 5,96 & 5,67 & 4,32 & 4,98 \\
\hline$R O A(\%)$ & 2,6 & 2,2 & 2,4 & 1,9 & 1,5 & 1,3 & 2 \\
\hline$R O E(\%)$ & 18,3 & 15,6 & 18,5 & 15,2 & 11,7 & 11,4 & 17,5 \\
\hline Indicator & 2009 & 2010 & 2011 & 2012 & 2013 & 2014 & 2015 \\
\hline $\begin{array}{l}\text { Bank cost to income } \\
\text { ratio (\%) }\end{array}$ & 45,1 & 45,9 & 54,6 & 55,3 & 55,9 & 47,1 & 49,4 \\
\hline $\begin{array}{l}\text { Liquid assets to deposits } \\
\text { and short term funding } \\
(\%)\end{array}$ & 30,0 & 16,5 & 13,8 & 12,7 & 14,0 & 17,1 & 37,2 \\
\hline $\begin{array}{l}\text { Provisions to } \\
\text { nonperforming loans } \\
(\%)\end{array}$ & 79,9 & 81,2 & 84,4 & 86,3 & 89,8 & 69,9 & 65,5 \\
\hline $\begin{array}{l}\text { Bank regulatory capital } \\
\text { to risk-weighted assets } \\
(\%)\end{array}$ & 14,7 & 15 & 14,9 & 14,9 & 15,5 & 17,6 & 19,2 \\
\hline
\end{tabular}

DOI: 10.2478/picbe-2018-0076, pp. 851-863, ISSN 2558-9652| Proceedings of the $12^{\text {th }}$ International Conference on Business 


\begin{tabular}{|l|r|r|r|r|r|r|r|}
\hline $\begin{array}{l}\text { Bank net interest margin } \\
(\%)\end{array}$ & 6,31 & 5,52 & 4,63 & 4,06 & 4,05 & 1,78 & 3,35 \\
\hline ROA (\%) & 0,5 & $-0,1$ & 0,1 & $-0,6$ & 0,45 & $-0,27$ & 0,9 \\
\hline ROE (\%) & 4 & -2 & 0,7 & -6 & 4,05 & $-2,6$ & 8,77 \\
\hline
\end{tabular}

Until 2009 the Romanian banking system profitability analysis reveals that ROA PICBE $\mid 855$ and ROE indicators were positive and growing. In 2003 profitability ratios recorded values. The downturn of these profitability ratios is due to increased competition in the Romanian banking sector but also the negative ascent of the net interest margins. The profitability of the Romanian banking system has turned negative in 2010 . Thus, for the first time since 1999 the banking system ended the year with a loss, mainly under the influence of the high provisioning costs, and of the deterioration of the exploitation result.

The profitability of the Romanian banking system doesn't show the same robustness as the growth of the Romanian economy. Romania is the first country in the EU if we consider the economic growth, but its banking system didn't display the same trend. The Romanian banking system faces many difficulties in recovering after the crisis. It ended 2014 with losses again. Starting with 2009, ROA evolution fluctuated a lot. The bank net interest margin displays a robust increase in 2015 against 2014, but this trend may moderate in the following years. The Romanian banking system couldn't close the gap with the levels reached during 2002-2011 for this ratio. Its lowest level was reached in 2014 when the Romanian banking system faced losses again (Table 2).

Some banks resized their networks and cut staff, but not sufficient. Foreignowned banks started deleveraging, but they didn't withdraw from the Romanian banking market. The market has seen even negative margins because of some banks (especially the Greek ones) that paid deposit interest at levels higher to cover their financing needs. Still, Romanian banking market is considered to have some potential in the future because it is underdeveloped especially in the rural areas (Bakor et al., 2012).

Cost-to-income ratio was high during 2002-2007 reaching levels above 60 percent, but then it started to decrease during 2008-2010. Starting with 2011, its trend fluctuated and its levels remained high at around 50-55\%. During 2014-2015 it increased again. These developments are very different from the situation we presented for the Bulgarian banking systems where this ratio decreased al almost half of its levels at the beginning of the analyzed period. The Romanian banks weren't able to perform an efficient cost management, didn't significantly cut their operational costs, especially in the salary expenses area, so they faced losses again in 2014.

The liquidity ratio strongly decreased during 2006-2012, but it recovered slowly during 2013-2014 and in 2015 it reached a level of 37,2\%, still much lower than the levels reached during 2002-2007. Due to increased capital and liquidity requirements of National Bank of Romania, the Romanian banking system had a rather adequate level of prudential indicators (Table 2).

Provisions to nonperforming loans have recorded a real boom after 2005 up to present. Despite their fluctuant developments and the fact that they decreased significantly after 2013, their level is higher than before the crisis. During 2002-2004, this

ratio displayed very low levels at around $12-16 \%$ and in 2007 it was around $60 \%$ (Table 2). The non-performing loans displayed a steady increase (this ratio increased ten times from around $2 \%$ up to $21 \%$ ) during 2007-2013, but after that it decreased to 12,3 DOI: 10.2478/picbe-2018-0076, pp. 851-863, ISSN 2558-9652| Proceedings of the $12^{\text {th }}$ International Conference on Business 
percent in 2015. The domestic credit to the private sector increased almost four times during 2002-2011 (from around 10 percent up to almost 40 percent) then decreased at around 30 percent in the following years 2012-2015 (Global Financial Development Database, 2016).

Interest rate spread steadily decreased during 2002-2007 from 16 percent down to 6,6\%. During 2007-2014 it became more stable and maintained between 5,2-6,7 percent with low fluctuations. In 2015 it decreased to 4,8 percent (Global Financial Development Database, 2016).

Hungary is generally considered one of the best performing transition countries, having been successful in achieving macroeconomic stabilization and in creating a market-driven economic system (Fischer and Sahay, 2000; Weder, 2001). In terms of financial sector reforms, the country is also considered in the advanced league (Bokros, 2001).

The degree of concentration was low in the Hungarian banking sector until the first half of 2000s'. At a lower level of efficiency, higher profits could be reached in Hungary than in other EU countries, as a consequence of the weak competition (some Hungarian banks gained oligopolistic profits on the retail market back then). Costs of financial intermediation decreased mainly in corporate markets, not in retail markets until 2002 (Várhegyi, 2004).

In Hungary, before the crisis (2002-2008), bank regulatory capital to riskweighted assets ratio fluctuated between 11-13\%. From 2009 it increased at almost 14 percent and during 2012-2015 it fluctuated between 16,3-17,4\%. However, the capitalization level of the Hungarian banking system is lower than in Bulgaria (22\%) and in Romania (almost 21\%). Because of the capitalization increase and the sharp decrease of the banking profits, ROE decreased at around 2,2-5,1\% during 2010-2015 from levels between $20-25 \%$ before the crisis, with 3 years of negative levels $(2011,2012,2014$ ) (Table 3).

Table 3. Dataset for Hungary

\begin{tabular}{|l|r|r|r|r|r|r|r|}
\hline Indicator & 2002 & 2003 & 2004 & 2005 & 2006 & 2007 & 2008 \\
\hline Bank cost to income ratio (\%) & 64,7 & 60,2 & 55,1 & 54,2 & 53,6 & 69,3 & 71,4 \\
\hline $\begin{array}{l}\text { Liquid assets to deposits and short term } \\
\text { funding (\%) }\end{array}$ & 44,8 & 40,1 & 33 & 33,8 & 33,7 & 28,7 & 28,1 \\
\hline Provisions to nonperforming loans (\%) & 50,8 & 47,3 & 83,5 & 65,1 & 57,1 & 64,8 & 43,6 \\
\hline $\begin{array}{l}\text { Bank regulatory capital to risk-weighted } \\
\text { assets (\%) }\end{array}$ & 13 & 11,8 & 12,4 & 11,6 & 11 & 10,4 & 12,3 \\
\hline Bank net interest margin (\%) & 5,21 & 4,50 & 5,60 & 5,03 & 5,18 & 4,39 & 3,77 \\
\hline ROA (\%) & 1,5 & 1,5 & 2 & 2 & 1,8 & 1,8 & 0,2 \\
\hline ROE (\%) & 20,2 & 19,3 & 25,3 & 24,7 & 24 & 22,9 & 13 \\
\hline Indicator & 2009 & 2010 & 2011 & 2012 & 2013 & 2014 & 2015 \\
\hline Bank cost to income ratio (\%) & 50,7 & 54,7 & 55,2 & 72,6 & 75,6 & 117,8 & 68,9 \\
\hline $\begin{array}{l}\text { Liquid assets to deposits and short term } \\
\text { funding (\%) }\end{array}$ & 30,2 & 26,2 & 28,3 & 27,2 & 29,7 & 47,8 & 21,5 \\
\hline Provisions to nonperforming loans (\%) & 32 & 39,1 & 45,8 & 48,6 & 51,7 & 59,4 & 60 \\
\hline $\begin{array}{l}\text { Bank regulatory capital to risk-weighted } \\
\text { assets (\%) }\end{array}$ & 13,9 & 13,9 & 13,8 & 16,3 & 17,4 & 16,9 & 16,9 \\
\hline Bank net interest margin (\%) & 3,68 & 3,99 & 3,34 & 3,38 & 3,44 & 2,08 & 4,48 \\
\hline ROA (\%) & 0,1 & 0,05 & $-0,1$ & $-0,4$ & 0,47 & $-1,57$ & 0,22 \\
\hline ROE (\%) & 12 & 3 & -8 & -3 & 5,1 & $-15,2$ & 2,2 \\
\hline
\end{tabular}


The Hungarian banking sector suffered significant losses during the crisis and ROE and ROA rates dropped dramatically. Country's weak economic performance compared with other Eastern European countries is just one factor contributing to declining of the banking profitability. The Hungarian banking market didn't display major mergers and acquisitions, because of the regulatory uncertainties. Many banks continued to compete for retail deposits at high interest rates. Competition for deposits became weaker after 2012 (Bakor et al., 2012).

Before the crisis, ROA displayed a stable level between 1,5-2\%. After the crisis erupted, this ratio decreased at negative levels, until 2014. In 2015 it reached 0,22 percent. During 2002-2007, the bank net interest margin stayed between 4,5-5,6\%. After 2008 it decreased from 4\% down to 2\% in 2014 (Table 3).

Cost-to-income ratio displayed a very interesting trend, different from the trend of this ratio in other CEE countries. During 2002-2008 it fluctuated between 53,6-71,4\%, then it started to increase during crisis from $50 \%$ in 2009 up to near $118 \%$ in 2014 . A decreased can be noticed in 2015 when this ratio decreased at almost 70 (Table 3).

A comparison of profitability within the CEE region during the crisis reveals that the Czech Republic and Poland are the leaders in CEE region, while Hungary is among the countries with the lowest profitability. As a result of the debt crisis and the conversion of loans denominated in $\mathrm{CHF}$, Hungarian banks recorded high negative profitability ratios.

Provisions to nonperforming loans ratio fluctuated during the entire period and it reached 59-60\% during 2014-2015. These levels are almost equal to the highest precrisis levels of 65\% reached in 2005 and 2007 (Table 3). During 2002-2008 the nonperforming loans had a share of $2-3 \%$ of the total gross loans. Starting with 2009 it increased up to $16,8 \%$ in 2013 (especially for the loans granted to the corporate sector). In 2015 it decreased again to 11,67\%. In Hungary and Romania, the peak of this ratio was reached in 2013 and then this ratio decreased during 2014-2015 at around 11-12\%, while in Bulgaria this ratio faced a constant increase during the entire period up to almost $20 \%$ in 2015. The domestic credit to the private sector in Hungary increased during 2002-2011, from 34,4\% up to almost 60-61\%. During 2012-2015 it steadily decreased to the same level of 2002-2003. In Bulgaria, the credit to the private sector was still high (56\%) in 2015 and so is the nonperforming credit, while in Romania and Hungary the domestic credit ranged between $30-36 \%$ in 2015 , almost half at it is Bulgaria. Interest rate spread fluctuated a lot during 2002-2015, from negative levels in 2003 up to the peak of 5,2\% in 2009. Most of the time, it ranged between 2-3\% (Global Financial Development Database, 2016). Liquidity decreased from 44\% in 2002 at $21,5 \%$ in 2015 , with low fluctuations during the entire period, except 2014 when it reached a high level of $47,8 \%$ (Table 3 ).

In Poland, at the end of the 90's, retail banking was growing fast. The share of consumption credits had increased in the total credits. After a period of increasing the number of branches, banks started to concentrate (mostly in the retail banking). One of the reasons for improving efficiency of Polish commercial banks was foreign entry in the Polish banking market (Hyz, 2011). The profitability of foreign banks in Poland was higher than the profitability of the domestic banks, just like in the entire CEE region (except Hungary) (Mérő and Endrész Valentinyi, 2003). Foreign owners dominate the banking sectors of Central and Eastern European countries (over 90\% of the total banking assets). Poland doesn't display a very concentrated banking market as Czech Republic or Hungary and that makes the Polish banking market highly competitive. The 
largest Polish bank is state owned and the share of the foreign assets of the total banking assets is around $60 \%$ which is the lowest number in the CEE region.

Bank regulatory capital to risk-weighted assets ratio fluctuated between 11,214\% during 2002-2011, except 2004-2005 when it was higher. After 2012 it improved and reached $16 \%$ in 2015 . The capitalization of the Polish banking sector is similar to the capitalization of the Hungarian banking system. ROE increased five time in the precrisis period. During 2008-2009 it was down to half just like ROA and after 2012 it decreased again from 14\% in 2012 to 9\% in 2015. During 2002-2007 ROA increased from 0,5-1,8\%. During 2008-2009 it decreased to half of its level. After 2011 it slowly decreased from 1,3\% down to 1,1\% and in 2015 it reached $0,8 \%$ and we predict this descendent trend will continue in the near future. A common feature of the CEE banking systems is the diminishing of the banking profits and profitability ratios starting with 2012-2013 up to present. During 2002-2011 the net interest margin decreased, then fluctuated around 3\% until 2013. Starting with 2014 it started to increase again, from very low levels of $2,4 \%$. However, these levels quite low, similar to the numbers reached during the crisis (2007-2010). Comparing with the other CEE banking systems, Romania was the most affected by the crisis in terms of the bank net interest margin and Poland performed better, but not as good as Bulgaria or even Hungary (Table 4).

Table 4. Dataset for Poland

\begin{tabular}{|l|r|r|r|r|r|r|r|}
\hline Indicator & 2002 & 2003 & 2004 & 2005 & 2006 & 2007 & 2008 \\
\hline Bank cost to income ratio (\%) & 80,8 & 87,3 & 64,3 & 59,6 & 58,3 & 58,4 & 55,3 \\
\hline Liquid assets to deposits and short term funding (\%) & 22,2 & 25,4 & 33,2 & 36,5 & 33,2 & 27,8 & 23,4 \\
\hline Provisions to nonperforming loans (\%) & 56,3 & 53,4 & 61,3 & 61,6 & 68,5 & 67,3 & 68,8 \\
\hline Bank regulatory capital to risk-weighted assets (\%) & 13,8 & 13,8 & 15,4 & 14,6 & 13,2 & 12 & 11,2 \\
\hline Bank net interest margin (\%) & 3,84 & 3,65 & 5,57 & 4,30 & 4,35 & 3,65 & 3,28 \\
\hline ROA (\%) & 0,5 & 0,5 & 1,4 & 1,6 & 1,7 & 1,8 & 1,5 \\
\hline ROE (\%) & 5,5 & 5,4 & 17,1 & 21,9 & 21 & 25,6 & 20 \\
\hline Indicator & 2009 & 2010 & 2011 & 2012 & 2013 & 2014 & 2015 \\
\hline Bank cost to income ratio (\%) & 53,8 & 52,9 & 52,5 & 52,3 & 54,6 & 50,1 & 52,9 \\
\hline Liquid assets to deposits and short term funding (\%) & 16,6 & 12,5 & 10,9 & 13,3 & 11,5 & 13,5 & 13,8 \\
\hline Provisions to nonperforming loans (\%) & 61,6 & 72,5 & 71,8 & 68,2 & 67,8 & 69,3 & 58,6 \\
\hline Bank regulatory capital to risk-weighted assets (\%) & 13,3 & 13,9 & 13,1 & 14,8 & 15,7 & 14,7 & 16 \\
\hline Bank net interest margin (\%) & 3,1 & 3,24 & 3,07 & 3,45 & 2,89 & 2,43 & 2,95 \\
\hline ROA (\%) & 0,8 & 1,1 & 1,3 & 1,3 & 1,1 & 1,1 & 0,8 \\
\hline ROE (\%) & 10,5 & 12,4 & 15,1 & 14 & 12,1 & 12,3 & 9,1 \\
\hline
\end{tabular}

During 2003-2014 cost-to-income ratio decreased from $87 \%$ down to $50 \%$. In 2015 it slowly increased at 52,9\%, but the cut of banking costs is significant in Poland. The Polish banking system cut its costs, modestly increased its net interest margin, but the overall profitability is still low. During 2002-2006 the liquidity improved from $22 \%$ up to $36 \%$, but during 2007-2011 it decreased three times down to almost $11 \%$ and then fluctuated between 11-13\% until 2015, thus, it remained low. During 2004-2014 the provisions for non-performing loans fluctuated between 61-72\%. In 2015 it slowly decreased ten percent, at a level of 58,6\% (Table 4). During 2002-2008, the nonperforming loans decreased ten times from $21 \%$ down to 2,8\%. Starting with 2009 it fluctuated between 4,2-5,2\%. During the entire period the domestic credit to the private 
sector increased from almost $13 \%$ up to almost 54\%. Poland and Czech Republic are the only CEE countries where the credit to the private sector increased all the analyzed years up to present. Poland reached a level similar to Bulgaria in 2015, but in Bulgaria the domestic credit decreased during the last years, while in Poland we have a solid increase during the years. In Czech Republic, this ratio was around 51\% in 2015, following a solid increase during 2002-2015, too. During 2003-2015 the interest rate spread ranged between 2,9-3,8\%, except in 2014 when it was 2,4\% and 2002 when it was at the highest level of 5,8\% (Global Financial Development Database, 2016).

Poland's banking sector has remained relatively stable through the crisis just like the entire Polish economy. Although ROE has not yet returned to pre-crisis levels, the fall in profitability was less severe than in other countries in the region. Revenue growth was driven by decreasing credit risk, a strong lending expansion and the cost efficiency increased. Although the Polish banking sector is one of the most stable in the region, its loan-to-deposit ratio is well above 100 percent, and it continues to rely on external funding sources and this can represent a serious threat for the Polish banking sector in the future.

The large majority of the foreign owned Polish banks display higher ROA than their parent Western banks more hit by the crisis, just like in the Czech Republic, while in Hungary the situation is just the opposite. Polish sustained economic growth helped banks to keep their loan portfolios clean, the share of its nonperforming loans being similar to the one in Czech Republic.

The Czech Republic chose a relatively slow pace of bank reform, while some other countries proceeded much faster (Hungary). Some of the countries that were relatively fast with bank reform were at the same time gradualist with financial account liberalization (Hungary). In Czech Republic, it was just an opposite situation. The Czech banking sector didn't take excessive exchange rate or maturity transformation risks and this prevented a deep banking crisis in the Czech Republic (Tuma, 2002).

Foreign investors in the banking sector started a sustained capitalization process in the Czech Republic, due to some higher net interest margins and significant revenues from increased bank fees (mainly due to the retail clients). The high growth of loans to households during 2005-2008, determined strongly growing profits at relatively low risk comparative to the corporate sector. The banks endured the economic crisis better than the Czech economy as a whole (Dubska, 2013).

In Czech Republic, bank regulatory capital to risk-weighted assets decreased slowly before the crisis during 2002-2008 from around 14\% down to 11\%. During 2009-2015, the Czech banks began to increase their capitalization and they reached high levels of $15-17 \%$. Because the capitalization decreased slowly by 2008, ROE didn't display major shifts. During 2002-2010 it ranged between 20-27\% and after 2011 it decreased below 20 percent. ROE was solid during the last decade, even during the crisis, well above the European average level. ROA slowly fluctuated during the entire period between $1,2-1,4 \%$. The net interest margin was rather stable, with low fluctuations between 2,6-3\% and only two years displayed ratios above 3 percent, before the crisis erupted. In 2014 it

decreased sharply at 0,7\%, but in 2015 it increased again to 2,6\%. These developments for bank net interest margin are singular among CEE analyzed countries. So, interest revenues decreased for the Czech banks, while for the Polish banks it remained rather constant (Table 5).

\section{Table 5. Dataset for Czech Republic}




\begin{tabular}{|l|r|r|r|r|r|r|r|}
\hline Indicator & 2002 & 2003 & 2004 & 2005 & 2006 & 2007 & 2008 \\
\hline Bank cost to income ratio (\%) & 63 & 56,8 & 58,8 & 54,1 & 54 & 50,2 & 46,3 \\
\hline Liquid assets to deposits and short term funding (\%) & 67,5 & 59,8 & 39,8 & 45,7 & 38,3 & 39,9 & 30,1 \\
\hline Provisions to nonperforming loans (\%) & 77,5 & 76,7 & 71,2 & 64,5 & 53,6 & 60 & 57,4 \\
\hline Bank regulatory capital to risk-weighted assets (\%) & 14,3 & 14,5 & 12,5 & 11,9 & 11,4 & 11,1 & 11,6 \\
\hline Bank net interest margin (\%) & 2,86 & 2,75 & 3,87 & 3,01 & 2,98 & 3,32 & 2,82 \\
\hline ROA (\%) & 1,2 & 1,2 & 1,3 & 1,4 & 1,2 & 1,3 & 1,2 \\
\hline ROE (\%) & 27,1 & 23,8 & 23,3 & 25,2 & 22,5 & 23,1 & 22 \\
\hline Indicator & 2009 & 2010 & 2011 & 2012 & 2013 & 2014 & 2015 \\
\hline Bank cost to income ratio (\%) & 39,7 & 41,6 & 43,4 & 41,4 & 41,5 & 42,1 & 45,8 \\
\hline Liquid assets to deposits and short term funding (\%) & 28,9 & 28,6 & 24,7 & 23,6 & 27 & 15 & 21 \\
\hline Provisions to nonperforming loans (\%) & 49,7 & 47,9 & 48,8 & 49,2 & 51,6 & 47,7 & 59,9 \\
\hline Bank regulatory capital to risk-weighted assets (\%) & 14 & 15,3 & 15 & 15,6 & 16,5 & 17 & 16,7 \\
\hline Bank net interest margin (\%) & 3,34 & 2,97 & 2,97 & 2,93 & 2,58 & 0,73 & 2,67 \\
\hline ROA (\%) & 1,5 & 1,4 & 1,2 & 1,4 & 1,3 & 1,3 & 1,2 \\
\hline ROE (\%) & 26 & 20,7 & 18,6 & 22 & 17,6 & 17,5 & 15,5 \\
\hline
\end{tabular}

PICBE | 860

Cost-to-income ratio decreased steadily during 2002-2009 from 63\% down to $39 \%$, but after 2010 it slowly increased over 40 percent. However, its level remained rather low and didn't overcame anymore the levels achieved before 2007. Profit from fees and commissions increased every year. In Czech Republic, high operating profits allowed banks to create sufficient buffers to cover losses from credit exposures (Table 5).

The liquidity decreased severely almost during the entire period we analyzed from $67 \%$ down to $15 \%$ in 2014 . During 2015 , it slowly improved up to near $21 \%$, but it remains low just like in Hungary, while in Poland it is even lower than that. Romania ranks first in terms of banking liquidity (Table 5).

Provisions to nonperforming loans decreased during 2002-2014 from 77\% down to around 50\%, except a significant increase in 2007 at $60 \%$ against 2006. In 2015 it also increased significantly from $47 \%$ in 2014 up to almost $60 \%$ (Table 5). These developments are supported by the trend of the bank nonperforming loans ratio that decreased almost four times before the crisis erupted from $8 \%$ in 2002 down to 2,8\% in 2008. After 2010 it ranged between 5,2-5,6\%, these levels being similar to the level of this ratio in 2003. Domestic credit to private sector increased the entire period just like in Poland, but the increase of this ratio in the Czech Republic wasn't so important as in Poland. In Czech Republic, the domestic credit doubled from 23\% up to 51,4\%, while in Poland it increased four times, from $13 \%$ up to 54\% in the same period 2002-2015 (Global Financial Development Database, 2016).

During 2002-2012, the interest rate spread ranged between 4,4-4,8\% with low fluctuations. Starting with 2012, it decreased below 4\% and reached 3,7\% in 2015. Given the trend of this ratio together with the increase of the cost-to-income ratio we can explain the downward trend displayed by the profitability ratios of the Czech banking system (Global Financial Development Database, 2016).

In 2015, Poland and the Czech Republic were considered high-growth markets, characterized by modest levels of financial intermediation, so the lending and asset growth can outpace GDP growth on a sustained basis in the near future. Hungary and Romania may be added to this group of countries. They regained their profits. Both 
banking markets displayed major improvements in the economic and banking sectors during 2014-2015 based on deleveraging and nonperforming loans restructuring (Raifeissen Bank, 2015).

\section{Conclusions}

If we rank the analyzed CEE banking sectors according to their capitalization ratio and PICBE | 861 net interest margin (the most relevant profitability ratio for the CEE banking sectors), Bulgaria ranks first, followed by Romania and Hungary. On the $4^{\text {th }}$ position it is Poland and the last position belongs to the Czech Republic. Bulgaria and Romania are better capitalized against their neighbors in the CEE region. Poland and Czech Republic displayed lower profitability ratios, but more stable than in Romania or Hungary. Romanian banking system were more severely hit by the recent financial crisis than the Bulgarian banking system in terms of profitability. Romanian banking systems faced losses three years, just like Hungary, because of a greater exposure to the loans denominated in foreign currency, especially to loans denominated in CHF. In Bulgaria, its exposure to the foreign exchange rate risk was much lower. Moreover, among the CEE analyzed countries, Bulgaria is the only country that proceeded to important and long-lasting cost cut-offs, but it still displays problems in the non-performing loans area, just like Romania does. Romania also proceeded to an important banking cost decrease, but lately, this trend has inversed, just like in the Czech Republic, while Hungary significantly cut off its banking costs, but it still displays a high level of this ratio, just like Poland. Romania and Bulgaria rank first according to their liquidity ratio, while in Hungary it significantly decreased in 2015, reaching a level similar to the one of the Czech Republic. Poland displays the lowest liquidity ratio in the CEE region, almost half of the Polish or Hungarian liquidity ratios, and the Polish banking liquidity slowly increased during the last years of the analyzed period.

\section{References}

Agoraki, M. \& Delis, M.D. \& Pasiouras, F. (2011). Regulations, competition and bank risktaking in transition countries. Journal of Financial Stability, 7(1), 38-48.

Altunbas, Y. \& Carbo, S. \& Gardener, E.P.M. \& Molyneux, P. (2007). Examining the Relationships between Capital, Risk and Efficiency in European Banking. European Financial Management, 13(1), 49-70.

Andrieș A.M. \& Căpraru B. \& Ieșan-Muntean Fl. \& Ihnatov I. (2016). The Impact of International Financial Crisis on Bank Performance in Eastern and Central European Countries. EuroEconomica, 35(1), 111-126.

Athanasoglou, P. \& Brissimis, S. N. \& Delis, M. (2008). Bank-specific, industry-specific and macroeconomic determinants of bank profitability. Journal of International Financial Markets, Institutions and Money, 18(2), 121-136.

Avadanei A. (2011). Credit risk assessment in the Romanian banking system. evidence from the recent financial crisis, CES Working Papers, III(4), 468-479.

Bákor K. \& Dietz M. \& Kincses A. \& Shvakman I. (2012). Eastern European banking: Time to shift gears, Banking and Securities (Europe), McKinsey Company, 1-17.

Beltratti, A. \& Stulz, R. M. (2012). The credit crisis around the globe: Why did some banks perform better during the credit crisis. Journal of Financial Economics, 105(1), 1-17.

Bokros, L. (2001). A Perspective on Financial Sector Development in Central and Eastern Europe, in Bokros et. al. (Eds.). Financial Transition in Europe and Central Asia (pp. 13-27). Washington: The World Bank. 
Căpraru, B. \& Ihnatov, I. (2014). Banks' Profitability in Selected Central and Eastern European Countries. Procedia Economics and Finance, 16, 587 - 591.

Claeys, S \& Vander Vennet R (2008). Determinants of Bank Interest Margins in Central and Eastern Europe: A Comparison with the West. Economic Systems, 32(2), 197-216.

Constâncio V. (2016). Challenges for the European banking industry. Conference on "European Banking Industry: what's next?", University of Navarra, Madrid, 7 July 2016, Retrieved from https://www.ecb.europa.eu/press/key/date/2016/html/sp160707_1.en.html

Demirgüç-Kunt, A. \& Huizinga, H. (1999). Determinants of Commercial Bank Interest Margins and Profitability: Some International Evidence. World Bank Policy Research Working Paper, 1900, 1-32.

Dubska, D, (2013). The Czech Banking Sector: Two Decades with the Shuttle Changes. Statistika, 93(1), 71-82.

Fischer, S. \& Sahay, R. (2000). The Transition Economies after Ten Years. IMF Working Paper, 30, 1-26.

Global Financial Development Database - GFDD, 2016, Retrieved from http://www.worldbank.org/en/publication/gfdr/data/global-financialdevelopment-database

Goddard, J. \& Molyneux, P. \& Wilson, J. O.S. (2004). The Profitability of European Banks: A cross-sectional and dynamic panel analysis. The Manchester School, 72(3), 363381.

Hyz A. (2011). Issues in consolidation and competition: case of Polish banking sector, International Journal of Humanities and Social Science, 1(8), 42-49.

Iannotta, G. \& Nocera, G. \& Sironi, A. (2007). Ownership structure, risk and performance in the European banking industry. Journal of Banking and Finance, 31(7), 2127 2149.

Mendes, V. \& Abreu, M. (2003). Do Macro-Financial Variables Matter for European Bank Interest Margins and Profitability?. CNVM, Lisabona, Retrieved from https://ecomod.net/sites/default/files/documentconference/ecomod2003/Abreu.pdf

Mérő K. \& Endrész Valentinyi M. (2003). The Role of Foreign Banks in Five Central and Eastern European Countries. Magyar Nemzeti Bank Banking Department, Working Paper, November 2003, 1-42.

Pasiouras, F. \& Kosmidou, K. (2007). Factors influencing the profitability of domestic and foreign commercial banks in the European Union. Research in International Business and Finance, 21(2), 222-237.

Petria N. \& Capraru B. \& Ihnatov I. (2015). Determinants of banks' profitability: evidence from EU 27 banking systems. Procedia Economics and Finance, 20, 518 - 524.

Radulescu M. \& Banica L. \& Sinisi C. \&Popescu S. (2018). The profitability and capital adequacy in Central and Eastern European countries in the light of the Basel III requirements - a forecast approach. Plos One, forcoming.

Raifeissen Bank - CEE Banking Sector: 2015 as a transition year. Retrieved from http://www.rbinternational.com/ceebankingsectorreport2015

Rivard R. J. \& Thomas C.R. (1997). The Effect of Interstate Banking on Large Bank Holding Company Profitability and Risk. Journal of Economics and Business, 49(1), 61-76. 
Roman A \& Tomuleasa I.I. (2014). Analysis of Profitability Determinants: Empirical Evidence of Commercial Banks in the New EU Member States. ISI Proceedings, 14 th

International Conference on Finance and Banking, Karviná: Silesian University, School of Business Administration, Ostrava, Czeck Republic, 372-383.

Tomuleasa I.I. \& Cocris V. (2014). Measuring the financial performance of the European systemically important banks. Financial studies, 4, 31-51.

Tuma Z. (2002). Banking sector development in the Czech Republic. East-West Conference Österreichische Nationalbank, Vienna, 1-18. Retrieved from https://pdfs.semanticscholar.org/8394/50b2968bf71c5617f9e47df7c63e09ca5 47b.pdf

Várhegyi E. (2004). Bank competition in Hungary. Acta Oeconomica, 54(4), 403-424.

Walko Z. (2003). The Bulgarian financial sector. Financial Stability Report, 8, ONB, 92106.

Weder, B. (2001). Institutional Reform in Transition Economies. How far have they come. IMF Working Paper, 1(114), 1-26. 